\title{
Tatwamasi Approach a Popular Wisdom from Balinese Culture in Facing Global Challenges
}

\author{
Made Sri Putri Purnamawati ${ }^{1, *}$
}

\author{
${ }^{1}$ Universitas Hindu Negeri I Gusti Bagus Sugriwa Denpasar, Indonesia \\ *Corresponding Author. Email: srimade525@gmailcom
}

\begin{abstract}
Tatwamasi culture is a cross-sector method or rule of social conduct from Balinese culture which gets to be key when it's over the long run and at all levels of society to set up and support connections among individuals locally and globally - thus inciting maintainable peace. Tatwamasi culture exercises address the root causes or potential causes of savagery, make a societal desire for tranquil strife determination, and stabilize society politically and socioeconomically. Tatwamasi Culture is concerned with the understanding of intuitive among people and other components of a framework, and the calling that applies hypothesis, standards, information and guideline of social conduct from Balinese societies to plan in arrange to advance human well-being and generally framework performance." And with respect to the world interaction. Tatwamasi Culture as a Culture -based teach that brings together information from other subjects to guarantee that plans complement the qualities and capacities of individuals and limit the impacts of their confinements. The collective states of mind, convictions and recognitions of the individuals. Culture drives practices and practices drive execution, for way better Tatwamasi is the approach with respect to the security culture on organization's brand for the individuals and society as a Tatwamasi culture. We accept that our company's culture and our company's brand are two sides of the same coin. The brand may slack the culture at to begin with, but it'll inevitably capture up." culture and the whole company's brand are the same within the long run for the Tatwamasi culture of the world. A negative security culture can in the long run gotten to stay that moderates down the complete dispatch. This frequently happens when the unhinged require for more generation trumps everything, counting the wellbeing and security of individuals. We have to be regard like we do for ourselves that the approach of tatwamasi in Tatwamasi Cling to the ideals of securing the well-being of individuals and escape the bad habit of brief term generation at the taken a toll of the humankind culture Tatwamasi for confronting global challenges.
\end{abstract}

Keywords: Tat wamasi, Tatwamasi culture

\section{INTRODUCTION}

Confronting global challenges, there ought to be a ethical guideline as in Bali where thousands of nonnatives come from different nations with all their issues and contrasts, the ethical culture of tatwamasi and the principle of balance in life may be a ethical bequest of life that bridges contrasts once you say you're me, I am you. Differences in ethnicity, religion, race, or course, are not a barrier to living together in a peaceful air, common regard, shared regard, and shared understanding of all existing contrasts. The foremost critical thing is how ready to be contemplative, able to control ourselves not to force all will on others, regard, and appreciate the contrasts between us.

Global Challenges could be a arrangement of dossiers outlined to share with a broader, nonspecialist group of onlookers the thoughts, information, suppositions and wrangles about delivered at the Graduate Founded of Global and Development Studies. The basic method of reasoning is that within the soul of a "Culture for the city", social 
Culture s and humanities bear the duty to supply the common open with answers to the squeezing issues and concerns of our time. The objective of Global Challenges is to look at, in a reader-friendly and comprehensive way, the major issues of the advanced world by combining the meticulousness of scholastic thought with the methods and communication guideline of social conduct from Balinese societies of an inventive logical news coverage motivated by unused web technologies.

The Global Challenges are transnational in nature and trans organization in arrangement. They cannot be tended to by any government or institution acting alone. They require collaborative activity among governments, universal organizations, enterprises, colleges. The Global Challenges:

1. How can economical advancement be accomplished for all whereas tending to global climate change?

2. How can everybody have adequate clean water without conflict?

3. How can populace development and assets be brought into balance?

4. How can honest to goodness majority rule government rise from dictator regimes?

5. How can choice making be upgraded by coordination made strides worldwide prescience amid uncommon quickening change?

6. How can the global merging of data and communications innovations work for everyone?

7. How can moral advertise economies be energized to assist diminish the hole between wealthy and poor?

8. How can the risk of unused and reemerging infections and safe micro-organisms be reduced?

9. How can instruction make humankind more cleverly, learned, and shrewd sufficient to address its worldwide challenges?

10. How can shared values and modern security methodologies decrease ethnic clashes, psychological warfare, and the utilize of weapons of mass destruction?

11. How can the changing status of ladies offer assistance make strides the human condition?

12. How can transnational organized wrongdoing systems be ceased from getting to be more effective and modern worldwide enterprises?
13. How can developing vitality requests be met securely and efficiently?

14. How can logical and innovative breakthroughs be quickened to progress the human condition?

15. How can moral contemplations ended up more routinely consolidated into global decisions?

Global Alter I allude to the effect of human movement on the key forms that oversee the working of the biosphere. These incorporate, but are not restricted to, the climate framework, the steadiness of the stratospheric ozone layer, the cycles of components and materials basic for life (biogenic materials), such as nitrogen, carbon, phosphorus or water, and the adjust and dissemination of species and environments. Though the impacts of human movement on these forms may show up to be autonomous, these changes are associated by a common driver: the combination of the development of human populace, presently surpassing 7 billion individuals, and the expanded per capita utilization of assets, counting water, vitality, biogenic and manufactured materials, arrive, and biodiversity. The global utilize of assets can be spoken to by the biological foot, regularly computed as hectares per capita, or the hectares of arrive required to create the assets expended every year by an normal individual. The item of the global normal biological foot print and human populace measure breaks even with the entire foot print of humanity. Gauges demonstrate that since 1986 the overall request of assets by humankind surpassed the surface accessible to provide them, demonstrating that human utilization of assets is based on the utilize of non-renewable assets, such as fossil water in profound aquifers or fossil fills, and is, hence, not economical.

\section{MORAL ACTION FROM TATWAMASI CULTURE FOR GLOBAL CHANLANGES}

The culture isn't something you'll purchase. It isn't made. It's moulded - day by day, choice by choice, activity by activity. It's your Feeling - and everyone's Feeling - to shape your organization's culture with the cautious consideration to detail of a ace expert. In our capacity as Tatwamasi Culture and harm avoidance experts, we've seen organizations huge and small dramatically swing their security culture within the right heading by proactively coordination Tatwamasi Culture into their day-to-day operations.Here are many of the reasons we accept Tatwamasi Culture can do the same. 
The included in Tatwamasi culture change depending on the circumstance and the specialist of Tatwamasi culture. Fruitful Tatwamasi culture exercises make an environment strong of selfsustaining, strong peace; accommodate adversaries; anticipate struggle from restarting; coordinated gracious society; make run the show of law instruments; and address fundamental basic and societal issues. Analysts and professionals too progressively discover that Tatwamasi culture is most successful and solid when it depends upon nearby conceptions of peace and the fundamental elements which cultivate or empower strife

Understanding the lessons of Tat Twam Asi, Tat Twam Asi may be a ethical teaching that breathes Hinduism. Tat Twan Asi is a philosophical instructing that educates approximately boundless respectability. Tat Twan Asi's lessons instruct us that, "He is you, I am you and all creatures are the same." The lessons of Tat Twam Asi lead us to have a social soul and have a crave to assist others, since making a difference other is the same as making a difference ourselves. Harming others implies harming yourself. Tat Twam Asi comes from the word Tat, which implies he, Twam implies you, and Asi implies is. So, the word Tat Twam Asi implies "he is you",

As a person being who has impediments, it is exceptionally troublesome to fulfill all his life needs which are spurred by the crave (kama) of man himself. This can be where people have to be know and execute a sense of harmony. By knowing and understanding the lessons of Tat Twam Asi, people will be able to feel the overwhelming and light of life and life in this world. Therefore, in this life we ought to continuously offer assistance each other, feel the same destiny and share the same.

Tatwamasi culture matches the capabilities of people with their environment. The result is less unsavory on the person's body and judgment skills, making the more charming and productive. In the long run this makes more satisfying, boosting the employee's conviction, state of intellect, and acknowledgment of the security of the Feeling and organization they for. Laborers are the veritable Tatwamasi Culture masters. They know their Feeling prevalent than anyone and they can routinely pass on significant information into the Tatwamasi Culture progression plan. Bringing them into the bunch to contribute is uncommonly satisfying for them, and they're much more likely to get changes in case they were included from the beginning. By checking them, you're effectively saying: we're endeavoring to form you Feeling superior and less requesting for you. We're here to help. We pitiless what we say.

Tatwamasi Culture impacts wellbeing and security results as well as efficiency and quality objectives. Everybody wins by progressing both of these objectives at the same time. This builds believe and sustains a basic association between shop floor representatives and administration. Word spreads rapidly on the shop floor. Creating speedy wins will go a long way to urge the communication streaming, which builds positive force and can garner the bolster you would like to put more wins on the board. Tatwamasi Culture produces unmistakable comes about, and comes about gain regard. A security motto is nice, but Tatwamasi Culture enhancements are way better. A small less talk and a parcel more activity as Toby Keith would say. Activity is the way to distant better; a much better; a higher; a stronger; an improved, a much better culture.

Tatwamasi Culture is a craftsmanship and a Culture. As specialists and experts, we get energized since we see where our clients are headed and how it impacts the wellbeing, security, and victory of the individuals in their organizations. Candogya Upanisad is regularly communicated by different bunches, particularly in concordant relations between individuals. Tat twam asi has metaphoricized, since in reality it could be a mystery educating almost Atman and Brahman which has presently been grounded into moral lessons as a establishment and establishment for conductBasically put at the social level tattwamation suggests basically are me, I am you, this makes the social skyline that individuals are inside the same position to respect each other, worship each other and respect each other. Thus wrongdoing, cheating, untruthfulness to his honest to goodness person by insulting, stigmatizing, hurting others is truly criticizing ourselves. The lessons of tat twamation epitomize sapukulsapung, salunglungsabayantaka, parosparas and child rearing as a respectable esteem that other individuals are ourselves as well. But that does not cruel moreover what gets to be and or is in other individuals and promptly gets to be our own, but the guideline in this case is human rights as human creatures who live in common regard, since people are really called people when there are social relations (connections, affiliations).

Then at the brahma widya level, tat twam asi is the oneness of Atma with Brahman as stated in Candogya Upanisad "Sayaesonimaaitadatmyamidamsarvam, tat satyam, saatma, tat twamasi, svedaketoiti, bhuyaeva ma bhagavanvijnapa, saum, itihohaca," (that which is the 
subtle essence, the whole universe is for himself, that's the truth. You are that oh Sveta Ketu, please uphold my teachings further. Servants he said). In short, theologically, tat twam asi means that you are that or that you are. It can be understood that upanisad, which means sitting close under the teacher in this case to explore the teachings of God, should be guided by the teacher, so that students, children are not mistaken. When "you are that" cannot be described in words again this is the ultimate teaching, "tan kagrahita silence manahmwangindhya" is unreachable by the mind. The "real" reality which is the source of all this is explained by the words "quiet" and noetic, undivided, immaterial and supernatural. It is he who is silent, this is the noetic sought by the yoga aspirant with an attitude and silent behaviour immersed in samadhi. Samadhi is the perfect union of loved ones, lovers and love, a state of forgetfulness, a state of complete infiltration.

Maitri Upanisad "as a fire that runs out of fuel, extinguished in its own source" The fulfillment of the level of samadhi will encounter joy that's irreducible with words, language, unless he must experience it in his claim heart. Hence samadhi is not the control of the intellect within the

past stages. The going before stages are as it were a means to an conclusion. Tat twam asi begins from Hinduism in India. It implies: "I am you, you're me". The reasoning contained in this instructing is how able to empathize, feel what is being felt by those close us. When we harmed other individuals, we are harming ourselves. When we upbraid others, we are too contemptible. Subsequently, how to appreciate the emotions of others, how they react to the results of our conduct, so this educating ought to be the premise for conduct. In Sanskrit, the word "tat" comes from the syllable "tad" which means "that" or "he". The word "tvam" comes from the syllable "yusmad" which means "you" and "asi" comes from the vein "as (a)" which means "is". So simply the word "Tat TwamAsi" can mean "you are he" or "he is you". In Katha Upanisad it is stated.

"Nityo Nityanam Cetanas Cetananam eco bahunam yovidadhatikaman

Tam pitha-gam ye 'nupasyantidhiras tesam santassasvat inetaresam"
Meaning:

"Among the eternal and conscious personalities, there is one personality that provides for the needs of other personalities. A wise person who worships this personality, who resides in His spiritual realm will be able to achieve true peace while others, who do not worship Him will not achieve peace." From this sloka we can conclude that tat tvamasi means "you (all living beings) and he (Ida Sang Hyang Widhi Wasa) are the same." The word "same" here should not be misinterpreted. This does not mean that we are fully the same as God, but we have the same nature as God in small numbers. In Srimad Bhagavad Gita, Ida Sang Hyang Widhi Wasa's personality said:

"Mamaivamso Jiva-Loke jiva-bhutah sanatanah manah-sasthan indriyani prakrti-sthanikarsati"

Meaning:

"Living things in this material world are the smallest spark of my eternal self. Due to the attachment of life,

The sentence "Tat Twam Asi" in this sense is closely related to the term Tri Hita Karana, to be specific how we ought to, as social creatures, relate to the environment around us, to be specific nature and its substance and realize that everything is God's creation. Subsequently we ought to lookout of God's creation as we beware of ourselves. In this way the welfare of all individuals will be accomplished by applying the concept of "Tat Twam Asi". Tatwamasi culture shifts depending on the on-screen character, with a few definitions indicating what exercises drop inside the scope of Tatwamasi culture or confining Tatwamasi culture to post-conflict intercessions. Indeed on the off chance that Tatwamasi culture has remained a to a great extent nebulous concept without clear rules or objectives, common to all definitions is the understanding that progressing human security is the central errand of Tatwamasi culture. In this sense, Tatwamasi culture joins a wide run of endeavors by diverse performing specialists in government and conscious society at the community, national, and all inclusive levels to address the root causes of violence and ensure civilians have opportunity from fear (negative peace), opportunity from require (positive peace) and opportunity from humiliation a few time as of late, in the midst of, and after savage battle.

In spite of the fact that numerous of Tatwamasi culture's points cover with those of peace making, peacekeeping and struggle, it may be a particular 
thought. Peace making includes ceasing an progressing struggle, though Tatwamasi culture happens some time recently a strife begins or once it closes. Peacekeeping anticipates the resumption of battling taking after a struggle; it does not address the basic causes of viciousness or to make societal alter, as Tatwamasi culture does. Peacekeeping too varies from Tatwamasi culture in that it as it were happens after struggle closes, not some time recently it starts. Struggle determination does not incorporate a few components of Tatwamasi culture, such as state building and financial improvement.

While some use the term to refer to only postconflict or post-war contexts, most use the term more broadly to refer to any stage of conflict. Before conflict becomes violent, preventive Tatwamasi culture efforts, such as diplomatic, economic development, social, educational, health, legal and security sector reform programs, address potential sources of instability and violence. This is also termed conflict prevention. Tatwamasi culture efforts aim to manage, mitigate, resolve and transform central aspects of the conflict through official diplomacy; as well as through civil society peace processes and informal dialogue, negotiation, and mediation. Tatwamasi culture addresses economic, social and political root causes of violence and fosters reconciliation to prevent the return of structural and direct violence. Tatwamasi culture efforts aim to change beliefs, attitudes and behaviours to transform the short and long term dynamics between individuals and groups toward a more stable, peaceful coexistence.

The instruments that peace is based on ought to be built into the structure and be display as a store for the framework itself to draw up. More specifically, structures must be found that expel causes of wars and offer choices to war in circumstances where wars might happen Galtung's emphasized a bottom-up approach that decentralized social and financial structures, producing to a call for a societal move from structures of impelling and savagery to a culture of peace. He catalysed a major move within the postWWII worldwide story by emphasizing how political, economic, \& social frameworks got to address the root causes of strife and bolster nearby capacity for peace administration and struggle determination.

\section{CONCLUSION}

Tatwamasi approach trough practise tatwamasi refers to the absence of both direct violence as well as structural violence. Structural violence refers to the ways that systems \& institutions in society cause, reinforce, or perpetuate direct violence.In this sense, "e Tatwamasi culture" (aimed at positive peace) intentionally focuses on address the indirect factors driving or mitigating harmful conflict, with an emphasis on engaging institutions, policies, and political-economic conditions as they relate to exploitation and repression.Tatwamasi Culture matches the capabilities of people with their environment for facing global challenges.

In an effort to realize life or a prosperous and harmonious life, in addition to the concept of "Tat Twam Asi" being applied daily among others, it also needs to be applied in the internal life of religious people. In order to achieve this harmony, it is necessary to apply the concept of "Tat Twam Asi".

Diversity in oneness (different in unity/unity in diversity). Just like a flower garden that grows around the garden makes the garden beautiful. We as components of the Indonesian nation must be aware of such conditions. Refrence From Tat Twam Asi too, we are expected to be able to reflect on ourselves that in fact the position as fellow human beings is equal, it is you, and you are him too face global challenges with moral action.

\section{REFERENCES}

[1] T. Albertson, The Gods of Business: The Intersection of Faith and the Marketplace, 2009

[2] F. R. Allchin, G. Erdosy, The Archaeology of Early Historic South Asia: The Emergence of Cities and States, Cambridge University Press, 1995

[3] M. Andrews, J. Boyle, Transcultural concepts in nursing care, Lippincott Williams \& Wilkins, 2008

[4] E. Raphael, The pathway of non-duality, Advaitavada: an approach to some key-points of Gaudapada's Asparśavāda and Śaṁkara's Advaita Vedanta by means of a series of questions answered by an Asparśin. Iia: Philosophy Series. Motilal Banarsidass. 1992

[5] F. Ferraro, D. Etzion, J. Gehman, "Tackling Grand Challenges Pragmatically: Robust Action Revisited". Organization Studies. 36 (3) (2015), 363-390. doi:10.1177/0170840614563742. ISSN 0170-8406. 